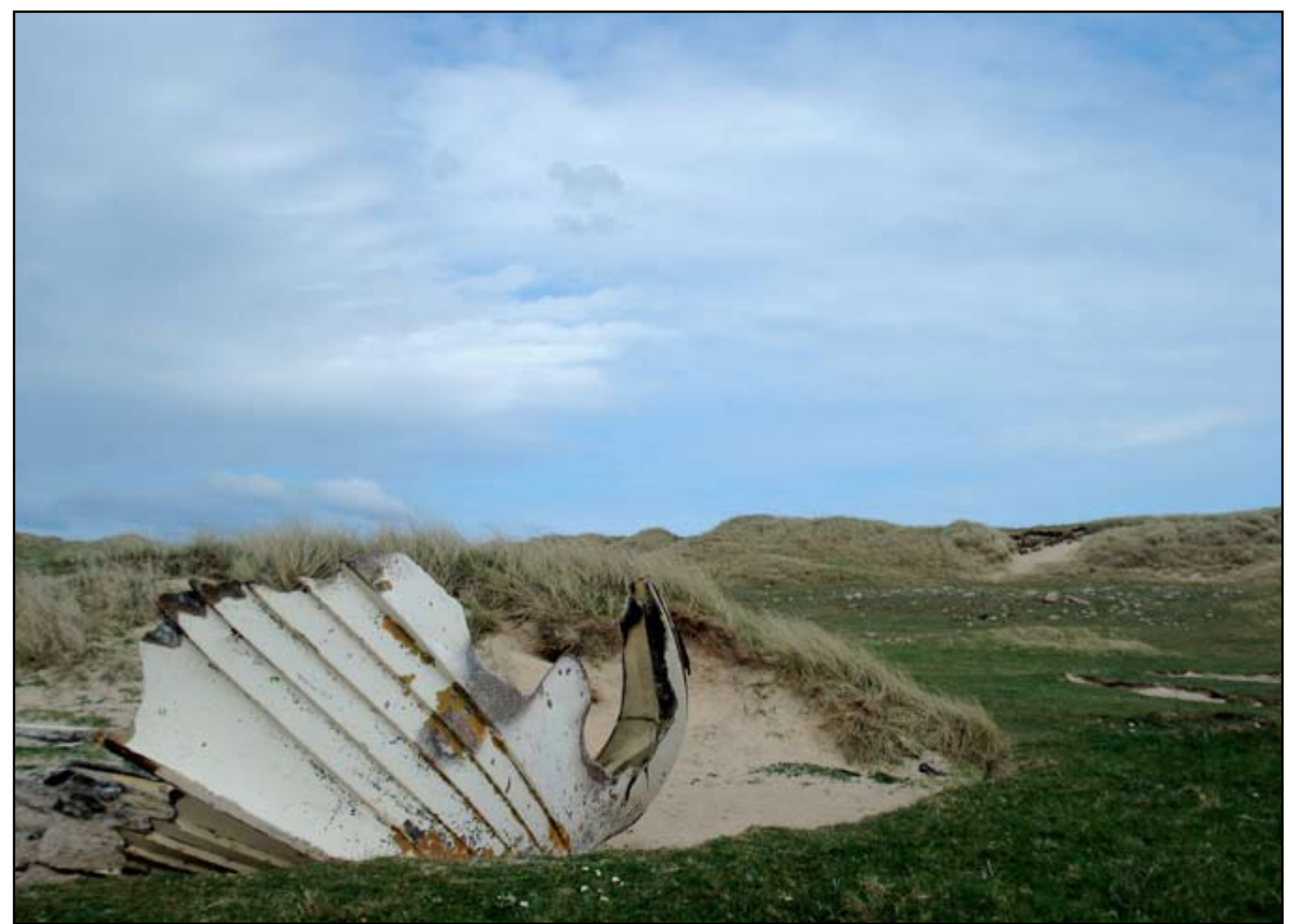

FIGURE 1

\title{
FACE TO FACE WITH THE LEWIS CHESSMEN
} EXPLORING CHILDREN'S ENGAGEMENT WITH MATERIAL HERITAGE AT THE NATIONAL MUSEUM OF SCOTLAND

\section{BY N. LUCY BULL}

$\mathrm{M}$ y fieldwork focused upon children's engagement with museum objects, through an extended period of ethnographic research at the National Museum of Scotland. My thesis subsequently explores the ways in which such objects are employed in museum education programmes and exhibitions to represent Scotland's archaeological heritage and identity and the ways in which these narratives are adopted and subverted by their child audience. I consider the agency of both children and objects within the power structures of the museum social network. Using the touring exhibition of the iconic Lewis Chessmen as a case study, I also explore the ways in which children in local communities in Scotland's peripheries relate to the National Museum of Scotland and how they employ material heritage to create their own narratives of identity and belonging. Throughout my research, the issue of 'authenticity' arose as something of considerable importance to my research participants and I use this concept as a way of thinking about trust and value in relation to the interaction between children and objects in museums. My research addresses important questions concerning the relationship between material heritage and conceptions of local and national identity in a way that employs the words and ideas not only of museum professionals, but, more importantly their audience. 삽 


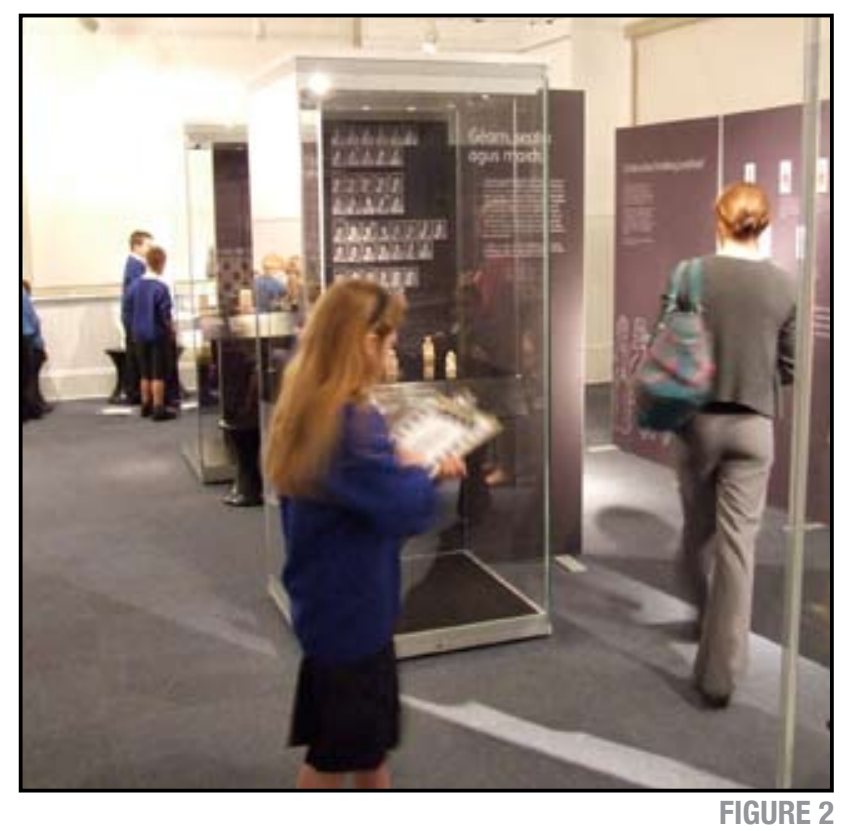

Tspent time working with children on the is1 land of Lewis during the temporary return of the Lewis Chessmen in a high-profile touring exhibition. This broken boat on Barvas beach alludes to the troubled local historical narratives shared by some of the people I met. The landscape is lonely and beautiful, mirroring my experience as a researcher in Lewis (Figure 1).

The importance of place became strikingly apparent as I researched the impact of the same exhibition at four very different locations. At each museum, the components of the exhibition assumed different meanings and significance for its audiences. Here, at Museum nan Eilean, Stornoway, local school children engage, upclose, with the small chess pieces and learn to play medieval board games (Figure 2).

Long walks around the town of Stornoway gave me time to both think about my fieldwork and get a feel for the place. Importantly, or so it seemed to me, the Chessmen followed me wherever I went. Here, the king has been incorporated into vibrant graffiti art, converting this space into a representation of Lewis and its perceived historical significance (Figure 3).

\section{"THE LANDSCAPE IS LONELY AND BEAUTIFUL, MIRRORING MY EXPERIENCE AS A RESEARCHER IN LEWIS."}
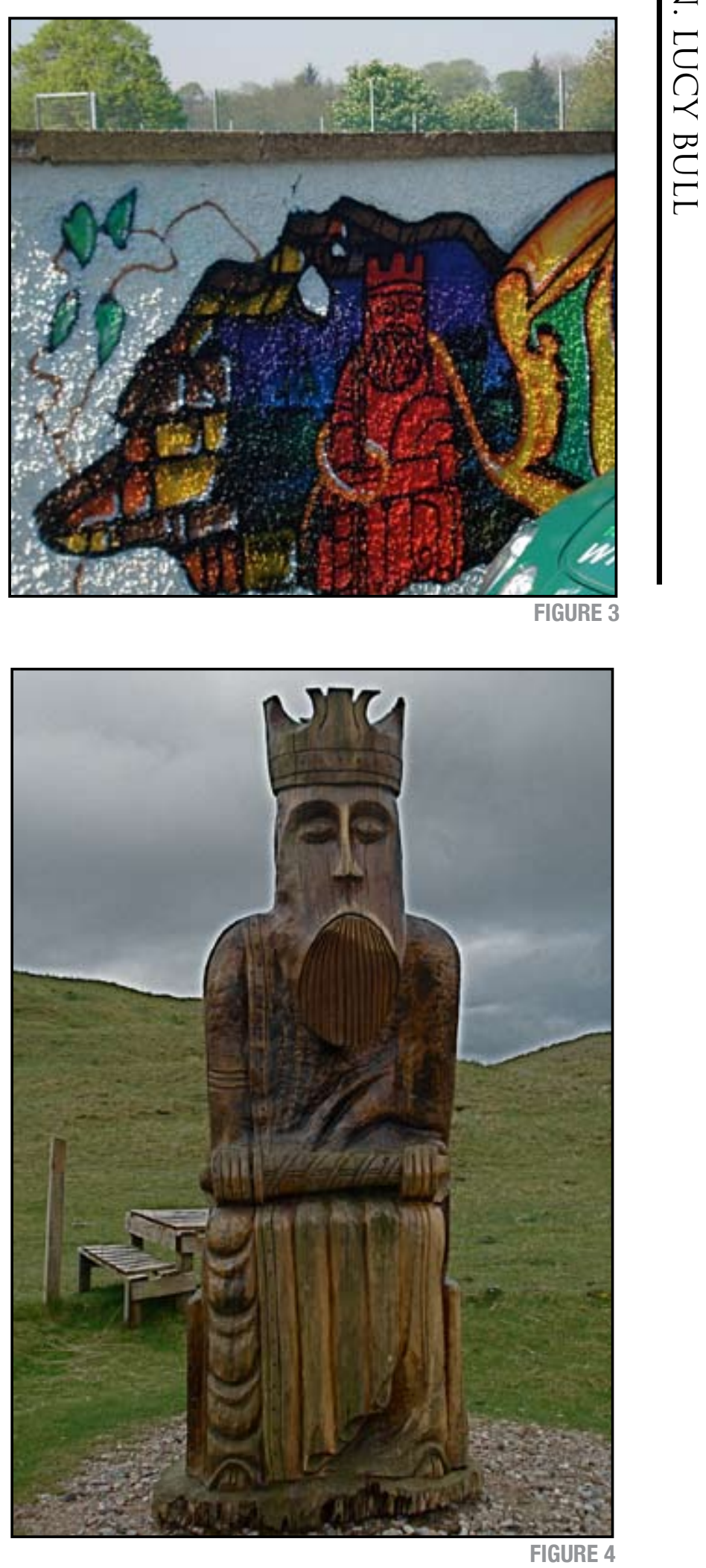

"This is my favourite because he's the king, the most powerful piece on the board" (Scott, P4, Knock Primary School, Stornoway). Taken at Uig Beach, Lewis (the traditional find site of the hoard), the carved figure in this photograph represents the dominant physical presence and personality of the Chessmen, which pervaded both the landscape of the island and my own research (Figure 4). 